\title{
Campylobacter pyloridis and acid induced gastric metaplasia in the pathogenesis of duodenitis
}

\author{
J I WYATT,* B J RATHBONE, $\dagger$ M F DIXON, $\ddagger$ R V HEATLEY $\dagger$ \\ From the Departments of *Pathology and $\nmid$ Medicine, St James's University Hospital, Leeds, and $\ddagger$ University \\ Department of Pathology, General Infirmary at Leeds
}

SUMMARY Biopsy specimens of gastric and duodenal mucosa from 290 patients were examined histologically for metaplasia and Campylobacter pyloridis. Estimates of $\mathrm{pH}$ on samples of fasting gastric juice from 55 of the patients were performed, and mucosal biopsy specimens from 33 patients were also cultured for $C$ pyloridis. Active duodenitis was seen in 34 duodenal biopsy specimens. Thirty $(88 \%)$ of the patients with active duodenitis had both $>5 \%$ gastric metaplasia in the duodenal specimen and $C$ pyloridis associated gastritis. These two factors coexisted in only $0.43 \%$ of patients with no duodenal inflammation. When $C$ pyloridis were seen histologically in duodenal biopsy specimens they were confined to areas of gastric metaplasia and never occurred in the absence of a polymorph infiltrate. Of the 55 patients with measurements of gastric juice $\mathrm{pH}$, gastric metaplasia was present in the duodenum in 20 of 42 with a pH of $<2.5$, and in 0 of 13 with a pH of $>2 \cdot 5$.

These results suggest that acid induced gastric metaplasia in the duodenum and $C$ pyloridis associated gastritis may be synergistic in the pathogenesis of duodenitis; the metaplastic gastric epithelium allows $C$ pyloridis to colonise the duodenal mucosa, where it produces an acute inflammatory response.

Traditionally, the pathophysiology of duodenal ulcer is related to excess secretion of gastric acid, ${ }^{1}$ and most current medical and surgical approaches to treatment are aimed, at least in part, at reducing acid output. The correlation between duodenal ulceration and high gastric acidity, however, is incomplete, implying the existence of other pathogenic factors. ${ }^{2}$ Microscopy of mucosa bordering on duodenal ulcers usually shows active duodenitis, and the same histological appearances may be seen in symptomatic patients in the absence of an overt ulcer crater. ${ }^{3}$ This has led to the concept of duodenitis and duodenal ulceration as representing different points in a disease spectrum with a common underlying pathogenesis. ${ }^{3-5}$

A consistent histological finding in duodenitis is the presence of gastric metaplasia of the duodenal epithelium, ${ }^{3}$ and this has been associated, both in $\operatorname{man}^{67}$ and in experimental animals, ${ }^{8}$ with high acidity of the duodenal contents. Most patients with duodenal ulcer have antral gastritis ${ }^{9}$ which is associated with colonisation by Campylobacter pyloridis. ${ }^{1011}$
Although these bacteria do not colonise small intestinal mucosa, they are often present on areas of gastric metaplasia in the duodenum. ${ }^{1012}$ This has led Marshall to postulate that duodenitis may be caused by secondary infection with $C$ pyloridis in areas of gastric epithelium in the duodenum. ${ }^{10}$

This study aimed to explore the relation between gastric acid, gastric metaplasia in the duodenum, and mucosal colonisation by $C$ pyloridis in dyspeptic patients with and without duodenitis or duodenal ulceration.

\section{Material and methods}

Single mucosal biopsy specimens from the duodenal bulb and gastric antrum and body were obtained from 254 consenting patients with non-ulcer dyspepsia (117 males, aged 16-80, mean age 47 years) during endoscopy. Similar sets of biopsy specimens from 23 preoperative duodenal ulcer patients and 13 patients who had had highly selective vagotomy (HSV) for duodenal ulcer were available from archive material.

The specimens were formalin fixed, routinely pro- 
Table 1 Gastric histology of paired antral and body biopsy specimens from 254 patients with non-ulcer dyspepsia and related to presence of $C$ pyloridis

\begin{tabular}{lcc}
\hline & \multicolumn{2}{l}{$C$ pyloridis } \\
\cline { 2 - 3 } Gastric histology & Present & Absent \\
\hline Normal & 0 & 106 \\
Antral gastritis, normal body & 39 & 1 \\
Body gastritis, normal antrum & 0 & 4 \\
Gastritis affecting antrum and body & 94 & 10 \\
\hline
\end{tabular}

cessed, and $3 \mu \mathrm{m}$ sections stained with haematoxylin and eosin, either the Warthin-Starry or a modified Giesma technique, ${ }^{13}$ for identification of mucosal $C$ pyloridis, and by alcian blue periodic acid Schiff for identification of metaplasia.

The presence and degree of gastric inflammation in the antrum and body were graded according to Whitehead's classification. ${ }^{14}$ The duodenal histology was graded as follows:

Normal A normal duodenal architecture with villus: crypt ratio of $>2: 1$ in most areas, with or without Brunner's glands above the muscularis mucosae, but with no increase in lamina propria cellularity or evidence of epithelial damage.

No significant duodenitis Architectural changes only, with blunted or distorted villi, but without a definite increase in mononuclear cells in the lamina propria or evidence of epithelial damage.

Chronic duodenitis A definite increase in mononuclear cells in the lamina propria, with evidence of epithelial damage.

Active duodenitis Intraepithelial neutrophils present; this was always a focal change, superimposed on a picture of chronic duodenitis.

In addition, the extent of gastric metaplasia in the duodenal biopsy specimen was subjectively assessed as nil, $<5 \%, 5-20 \%$, or $>20 \%$ of the surface epithelium. Gastric heterotopia was diagnosed when specialised gastric glands of body type were present in the duodenum.

Additional antral biopsy specimens from 33 of the patients were homogenised and cultured on heated blood agar at $37^{\circ} \mathrm{C}$ under microaerophilic conditions for at least four days, as previously described for isolation of $C$ pyloridis. ${ }^{15}$
Samples of fasting gastric juice aspirated at th $\stackrel{0}{\rightleftarrows}$ start of endoscopy were available from 55 of the. dyspeptic patients for estimation of $\mathrm{pH}$.

Statistical analysis was by the Mann-Whitney test for gastric juice $\mathrm{pH}$ in patients with and without gastric metaplasia in the duodenum, and elsewhere by the $\chi^{2}$ test, with Yates's correction, where appropre ate.

\section{Results}

\section{BACTERIOLOGY}

Colonies of campylobacters were isolated from 1 角 antral biopsy specimens; these were all identified as Cpyloridis by their characteristic biotyping, ${ }^{16}$ includa ing oxidase, catalase, and urease positivity, an\&o nalidixic acid resistance. Of the 33 cases culturedoo Cpyloridis were obtained from 16 of 21 (76\%) of patients in whom Cpyloridis were identified histologi cally, and from none of the 12 who were histologically Cpyloridis negative. This, therefore, confirmed the specificity of the histological technique in the identification of Cpyloridis, which, in our hands? provided the more sensitive method for detection of mucosal colonisation of the upper gastrointestinad tract.

\section{COLONISATION WITH CAMPYLOBACTER PYLORIDIS}

All patients who had duodenal ulcer or HSV had hiš tological evidence of chronic gastritis associated wit Cpyloridis colonisation. Table 1 shows the gastric his $\overrightarrow{0}$ tology of the patients with non-ulcer dyspepsia. One hundred and forty eight cases showed chronic gas tritis, and in $133(89.8 \%)$ this was histologically asso? ciated with $C$ pyloridis. One hundred and six pairs of gastric biopsy specimens showed no evidence of chronic gastritis, and no mucosal bacteria were detected in any of these.

Overall, 169 of the 290 patients studied (58.3\% were histologically $C$ pyloridis positive. Table 2 shows the relation between the duodenal histology and the presence of $C$ pyloridis in the stomach for all patient Ninety seven per cent of patients with active duo denitis were Cpyloridis positive, compared with $53.1 \%$ of patients without active duodenal inflammation.

Table 2 Duodenal histology from all 290 patients studied and related to gastric colonisation by Cpyloridis

\begin{tabular}{|c|c|c|c|}
\hline Duodenal histology & Normal stomach & $\begin{array}{l}\text { Campylobacter } \\
\text { positive gastritis }\end{array}$ & $\begin{array}{l}\text { Campylobacter } \\
\text { negative gastritis }\end{array}$ \\
\hline $\begin{array}{l}\text { Normal } \\
\text { No significant duodenitis } \\
\text { Chronic duodenitis } \\
\text { Active duodenitis }\end{array}$ & $\begin{array}{r}86 \\
13 \\
6 \\
1\end{array}$ & $\begin{array}{r}107 \\
18 \\
11 \\
33\end{array}$ & $\begin{array}{r}11 \\
0 \\
4 \\
0\end{array}$ \\
\hline
\end{tabular}


Role of Cpyloridis and gastric metaplasia in duodenitis

Table 3 Presence of gastric metaplasia related to duodenal histology in patients with duodenal ulcer after HSV and in those with non-ulcer dyspepsia

\begin{tabular}{|c|c|c|c|c|c|c|c|c|c|c|c|}
\hline \multirow[b]{2}{*}{ Duodenal histology } & \multicolumn{4}{|c|}{ Duodenal ulcer $(n=53)$} & \multicolumn{3}{|c|}{$H S V(n=13)$} & \multicolumn{4}{|c|}{ Non-ulcer dyspepsia $(n=254)$} \\
\hline & $0 \%$ & $<5 \%$ & $5-20 \%$ & $>20 \%$ & $0 \%$ & $<5 \%$ & $5-20 \%$ & $0 \%$ & $<5 \%$ & $5-20 \%$ & $>20 \%$ \\
\hline $\begin{array}{l}\text { Normal } \\
\text { No significant }\end{array}$ & 2 & 2 & 0 & 0 & 6 & 0 & 0 & 162 & 24 & 7 & 1 \\
\hline $\begin{array}{l}\text { duodenitis } \\
\text { Chronic duodenitis } \\
\text { Active duodenitis }\end{array}$ & $\begin{array}{l}3 \\
2 \\
1\end{array}$ & $\begin{array}{l}0 \\
1 \\
0\end{array}$ & $\begin{array}{l}0 \\
0 \\
5\end{array}$ & $\begin{array}{l}0 \\
0 \\
7\end{array}$ & $\begin{array}{l}5 \\
0 \\
0\end{array}$ & $\begin{array}{l}0 \\
0 \\
1\end{array}$ & $\begin{array}{l}0 \\
0 \\
1\end{array}$ & $\begin{array}{r}15 \\
5 \\
0\end{array}$ & $\begin{array}{l}4 \\
6 \\
1\end{array}$ & $\begin{array}{r}4 \\
6 \\
11\end{array}$ & $\begin{array}{l}0 \\
1 \\
7\end{array}$ \\
\hline
\end{tabular}

GASTRIC METAPLASIA IN THE DUODENUM Gastric metaplasia was identified in 89 of $290(30 \cdot 7 \%)$ duodenal biopsy specimens; table 3 shows the prevalence of metaplasia in the different patient groups and its relation to duodenal histology. In 39 biopsy specimens there were small foci of gastric metaplasia, occupying less than $5 \%$ of the mucosal surface; these small groups of metaplastic cells showed a tendency to occur at the tips of villi, and were rarely associated with active duodenitis. More extensive gastric metaplasia, assessed as $>5 \%$ of the epithelial surface, was present in 50 specimens; in 12 this was an isolated finding, not associated with features of duodenitis, although villous blunting was often present, while in $31(62 \%)$ of the specimens there was active duodenitis. Thus although small foci of metaplasia often occur in otherwise normal duodenal mucosa, there was a significant association between more extensive gastric metaplasia $(>5 \%)$ and active duodenitis $(\mathrm{p}<$ 0.001).

There was no significant difference in the preva-

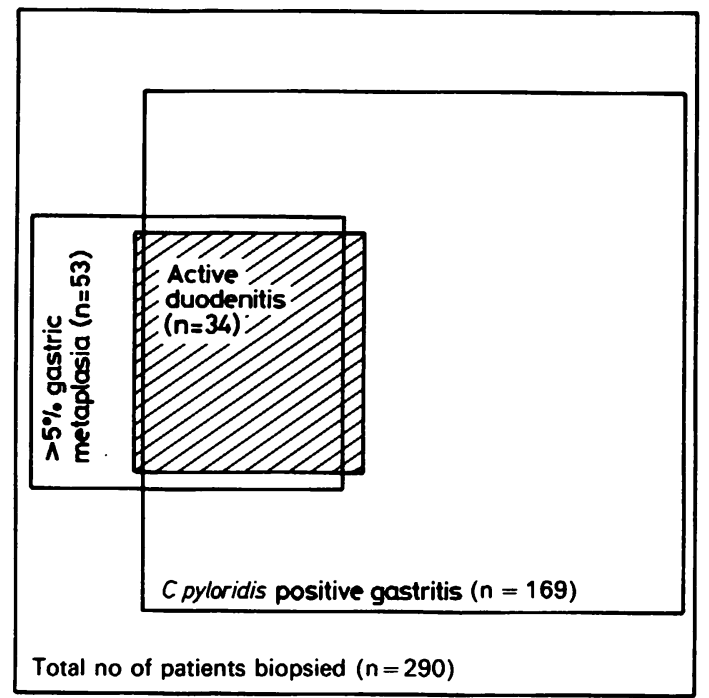

Fig 1 Distribution of active duodenitis of $>5 \%$ gastric metaplasia, and gastritis associated with C pyloridis in 355 duodenal biopsy specimens. lence of gastric metaplasia in the duodenum between the patients with gastric Cpyloridis $(33.5 \%)$ compared with those without $(28.7 \%)$. Similarly, the presence of gastritis had no effect on the finding of gastric metaplasia in the duodenum, except that such metaplasia was not seen in patients in whom atrophic gastritis with intestinal of pyloric metaplasia was present in the body mucosa. The gastric mucosa was normal in the four cases with heterotopic gastric mucosa in the duodenum.

\section{ACTIVE DUODENITIS}

Active duodenitis was present in 34 of the total 290 duodenal biopsy specimens from all groups. This included 19 biopsy specimens from patients with nonulcer dyspepsia patients, 13 from patients with duodenal ulcer, and two from the group who had had HSV. In 30 of these cases there was both $>5 \%$ gastric metaplasia in the duodenum and gastric colonisation by $C$ pyloridis (fig 1). A further four patients (all with non-ulcer dyspepsia) had both gastric metaplasia of $>5 \%$ and gastric campylobacter but without active duodenitis; three had chronic duodenitis, and only one had a histologically normal duodenal biopsy specimen. Thus the combination of $>5 \%$ gastric metaplasia and gastritis associated with $C$ pyloridis occurred in $88 \%$ cases with active duodenitis and in only $0.43 \%$ ( 1 of 235 ) patients without duodenal inflammation.

In the Warthin-Starry or Giemsa stained sections, Cpyloridis were observed in 19 of $36(53 \%)$ of biopsy specimens showing active duodenitis; the bacteria were only found on areas of gastric metaplasia, never occurred in the duodenum in tha absence of a polymorph infiltrate, and were seen as often in the patients with non-ulcer duodenitis as in those with duodenal ulcers. Polymorph infiltration of the epithelium occurred predominantly in areas of gastric metaplasia (fig 2 ) and was often closely associated with surface bacteria (figs 3 and 4 ).

In one case of active duodenitis the stomach was histologically normal and no $C$ pyloridis were detected. In two cases there were only small foci of gastric metaplasia in the duodenal biopsy specimen; both of these patients showed Campylobacter 


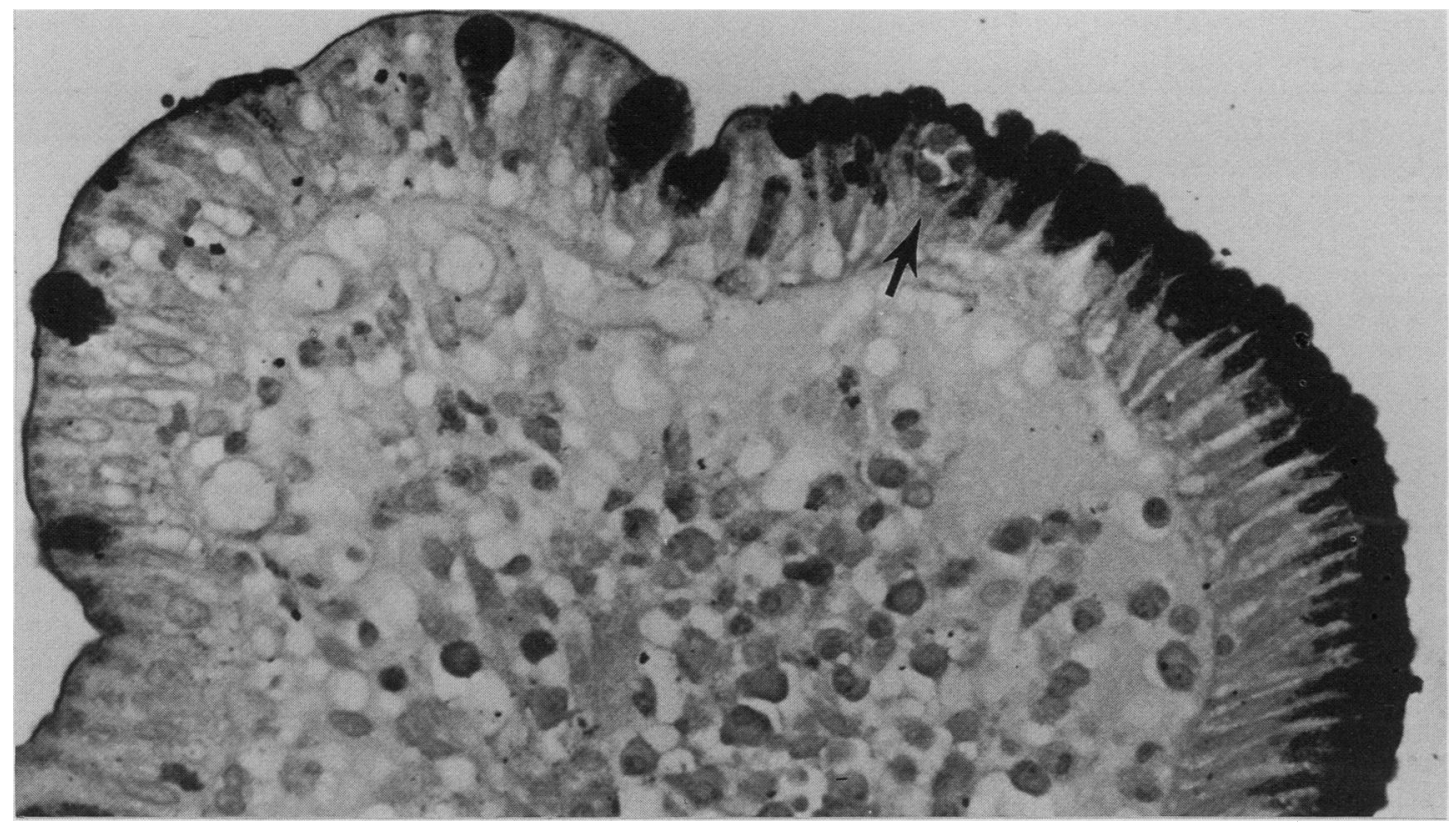

Fig 2 Duodenal mucosa showing gastric metaplasia of surface epithelium. Intraepithelial neutrophil is present (arrow) in metaplastic area. (Alcian blue/periodic acid Schiff).

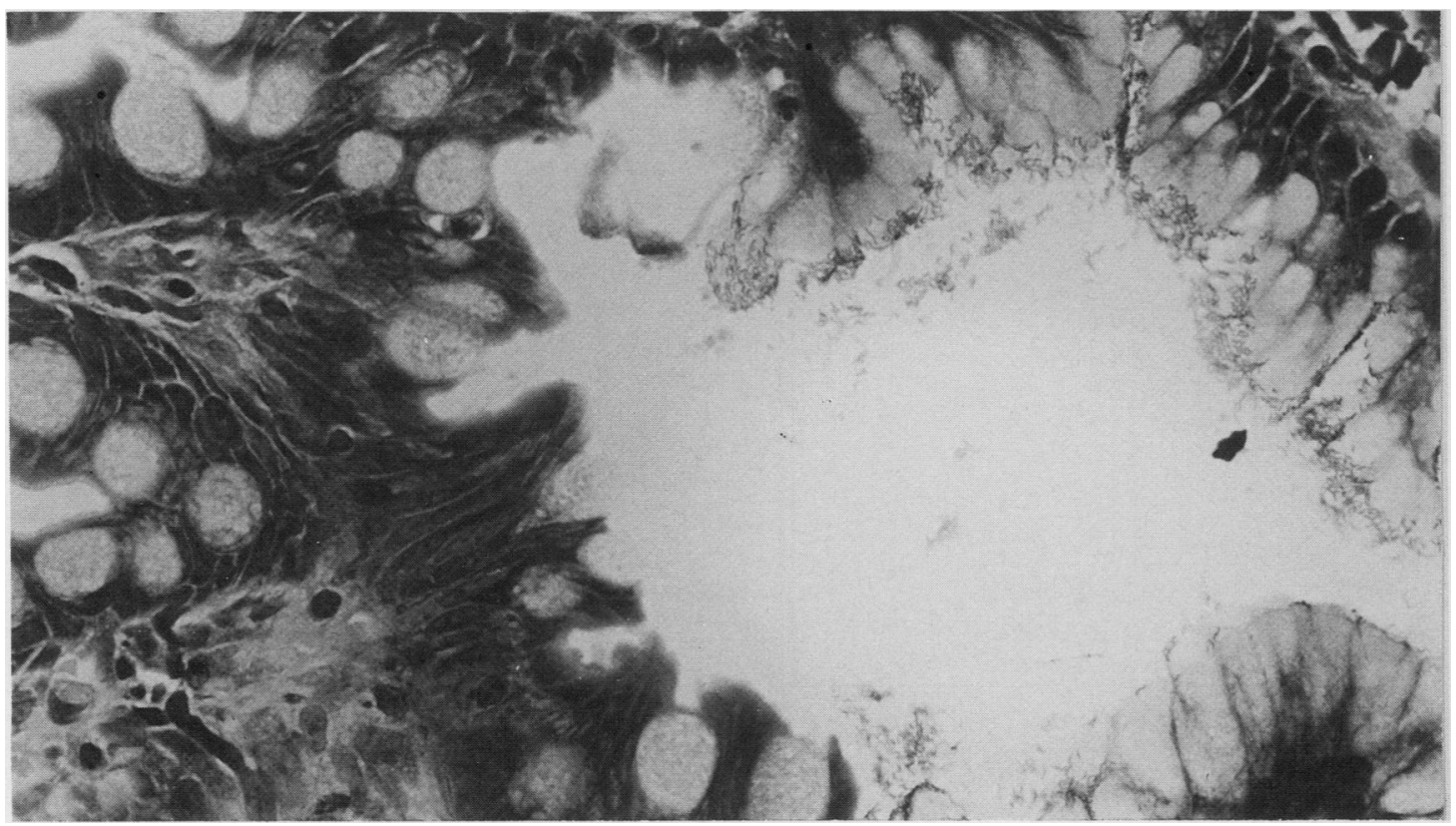

Fig 3 Mucosal colonisation by Cpyloridis restricted to areas of gastric epithelium. 


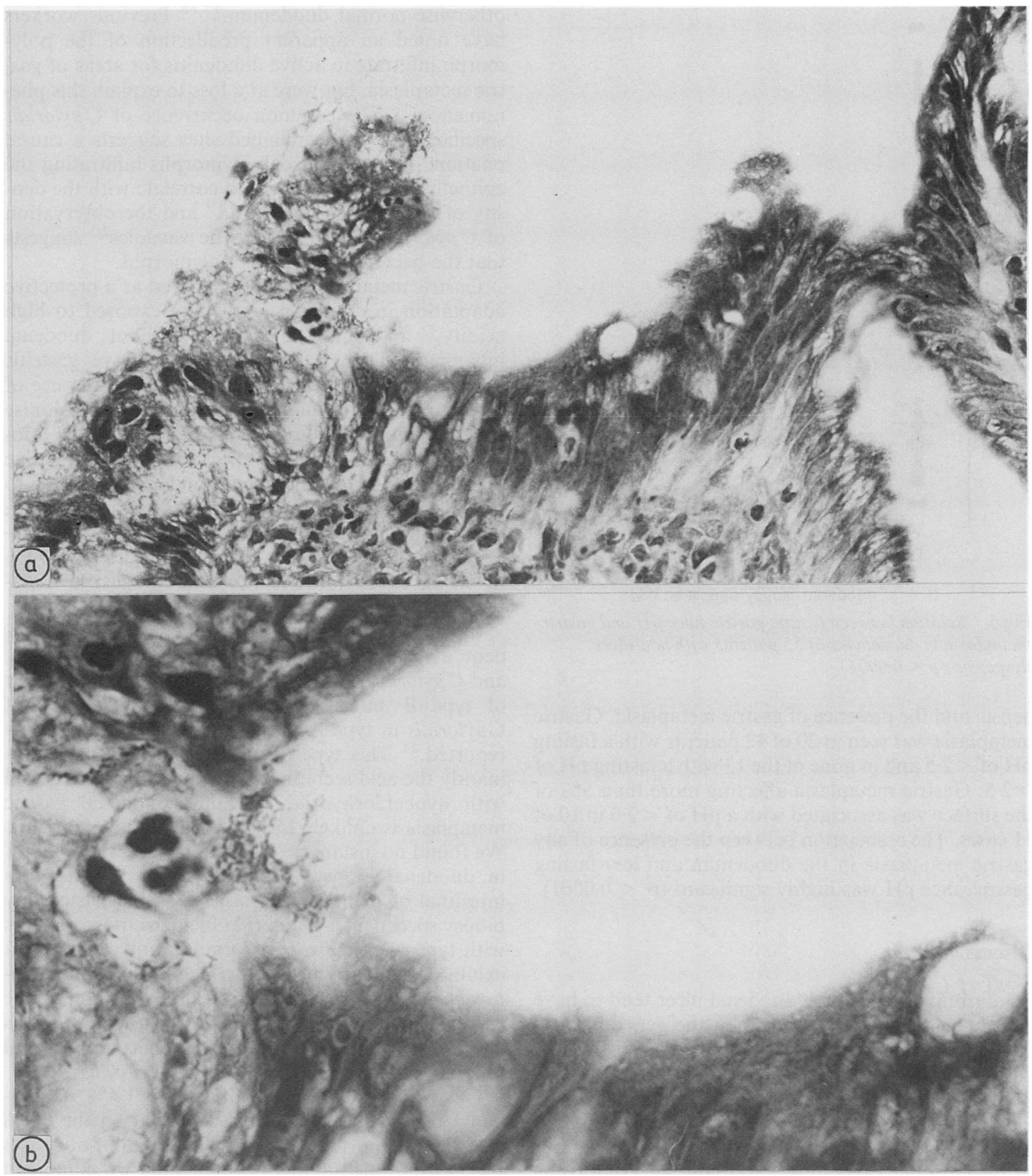

Fig 4 (a) Duodenal biopsy specimen showing active duodenitis. $C$ pyloridis can be seen in gastric metaplasia (left of picture); (b) higher magnification of (a) to show proximity of intraepithelial neutrophil to surface $C$ pyloridis. (modified Giemsa.)

colonisation, both of the stomach and of the foci of gastric metaplasia. Only one patient positive for gastric Campylobacter with active duodenitis showed no gastric metaplasia in the duodenal biopsy specimen.
GASTRIC JUICE PH AND GASTRIC METAPLASIA IN THE DUODENUM

Fig 5 shows the relation between the fasting gastric juice $\mathrm{pH}$ estimates in 55 patients with non-ulcer dys- 


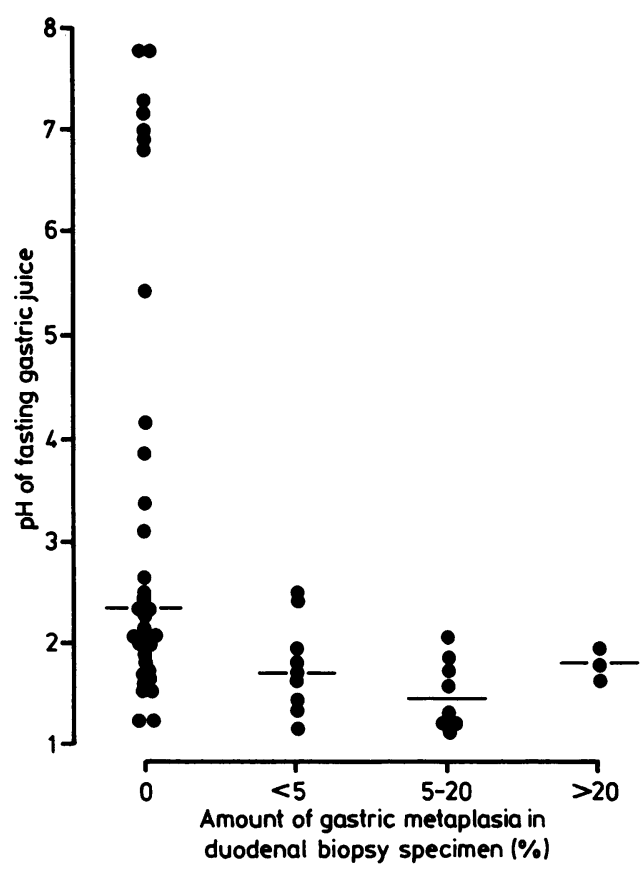

Fig 5 Relation between fasting gastric juice $\mathrm{pH}$ and gastric metaplasia in duodenums of 55 patients with non-ulcer dyspepsia $(p<0.0001)$.

pepsia and the presence of gastric metaplasia. Gastric metaplasia was seen in 20 of $\mathbf{4 2}$ patients with a fasting $\mathrm{pH}$ of $<2.5$ and in none of the 13 with a fasting $\mathrm{pH}$ of $>2 \cdot 5$. Gastric metaplasia affecting more than $5 \%$ of the surface was associated with a pH of $<2.0$ in 10 of 11 cases. The association between the presence of any gastric metaplasia in the duodenum and low fasting gastric juice $\mathrm{pH}$ was highly significant $(\mathrm{p}<0.0001)$.

\section{Discussion}

As a group patients with duodenal ulcer tend to have a higher gastric acid output than the general population. These patients have an increased sensitivity to gastrin ${ }^{2}$ and an increased rate of gastric emptying, ${ }^{1}$ both abnormalities resulting in material of low $\mathrm{pH}$ entering the duodenum. ${ }^{2}$ Duodenal ulcers are prone to recur, and duodenitis may persist between periods of ulceration, suggesting "a diathesis comprising hyperchlorhydria and duodenitis proceeding to duodenal ulcer". ${ }^{14}$ Our data suggest that the presence of Cpyloridis forms the missing link in the pathogenesis of this duodenal ulcer diathesis, acting synergistically with acid induced gastric metaplasia to cause mucosal damage in the duodenum.

Gastric metaplasia is closely associated with the presence of duodenitis, although it can occur in the otherwise normal duodenum. ${ }^{1718}$ Previous workers $\stackrel{\oplus}{*}$ have noted an apparent predilection of the poly- 을 morph infiltrate in active duodenitis for areas of gas- $\overrightarrow{\vec{F}}$ tric metaplasia, but were at a loss to explain this phe- $\stackrel{\rho}{\rightarrow}$ nomenon. ${ }^{18}$ The common occurrence of $C$ pyloridis specifically in these inflamed sites suggests a causal $\frac{\overline{\bar{N}}}{\mathrm{n}}$ relation. The number of polymorphs infiltrating the $\frac{\bar{\sigma}}{\sigma}$ epithelium has been shown to correlate with the den- $\triangle$ sity of bacterial colonisation, ${ }^{19}$ and the observation $\%$ of $C$ pyloridis within phagocytic vacuoles ${ }^{20}$ suggests $\vec{\circ}$ that the bacteria can attract polymorphs.

Gastric metaplasia has been viewed as a protective $\vec{\omega}$ adaptation in duodenal epithelium exposed to high $\stackrel{?}{=}$ acidity, ${ }^{7}$ and may be present without duodenalo inflammation. In patients who also have gastritis ${ }_{0}$ associated with $C$ pyloridis, however, the presence of $\%$ gastric metaplasia allows these bacteria to colonise the duodenum. We observed $C$ pyloridis in the duo- $\nexists$ denum in $53 \%$ of biopsy specimens showing active 의 duodenitis, but this may be an underestimate due to the sampling error of a single biopsy specimen. Steer, using scanning electron microscopy, detected the bacteria on mucosa adjacent to duodenal ulcers in $73 \% \stackrel{\rho}{\sim}$ of cases, again restricted to sites of gastric meta- $\vec{\varphi}$ plasia. $^{12}$

It could be argued that our data reflect the independent association of duodenitis, gastric metaplasia, and $C$ pyloridis colonisation, with the common factor of type B antral gastritis. The low incidence of Cpyloridis in type A autoimmune gastritis has been $\frac{O}{\mathbb{D}}$ reported. ${ }^{21}$ This type of gastritis, affecting predom- $\cong$ inantly the acid secreting body mucosa, is associated $\overrightarrow{\overrightarrow{0}}$ with hypochlorhydria, and thus duodenal gastric 3 metaplasia is unlikely to be present in these patients. We found no instances of gastric metaplasia of $>5 \%$. in duodenal biopsy specimens from patients with응 intestinal or pyloric metaplasia in their gastric body biopsy specimen, a group that includes those patients 3 . with type A gastritis. Furthermore, only one patient exhibited concurrent gastric metaplasia and $\mathrm{Cam}-₹$ pylobacter negative gastritis, so that we were unable $\mathrm{O}$ to resolve the question of whether duodenitis was associated simply with the presence of antrato inflammation, or specifically with $C$ pyloridis.

Gastric heterotopia was present in $1.4 \%$ of duodenal biopsy specimens; this is similar to the $0.9 \%$ N prevalence reported by Shouska. ${ }^{18}$ In all of our casesN the gastric mucosa was normal; thus we could not ${ }_{\sigma}^{\omega}$ observe the effect of $C$ pyloridis colonisation on this heterotopic (presumed congenital) gastric epitheliume not associated with inflammation.

If a combination of gastric metaplasia induced by excess acid and $C$ pyloridis infection are necessary for duodenal inflammation and ulceration to develop, $\mathbb{D}$ then removal of either of these factors would be expected to result in healing. We have previously 
reported that patients treated for duodenal ulcer with HSV remain colonised with gastric $C$ pyloridis. ${ }^{22}$ In the present study the prevalence of gastric metaplasia in the patients who had had HSV $(15 \%)$ is significantly less than the $65 \%$ prevalence seen in the preoperative patients with duodenal ulcer $(p=0.01)$. If gastric metaplasia is an adaptive response to high duodenal acidity then these results imply that it is reversed by treatment aimed at reducing acid output. This change is accompanied by a significantly lower prevalence of duodenitis than in patients with duodenal ulcer.

Healing of duodenal ulcer by bismuth compounds, which are bactericidal to $C$ pyloridis, but do not affect acidity, is associated with eradication of $C$ pyloridis, improvement in duodenitis, ${ }^{23}$ and longer interval before ulcer relapse than is seen in patients treated with histamine $\mathrm{H} 2$ receptor antagonists. ${ }^{24-26}$ The mode of action of bismuth is uncertain as it may also protect the ulcer base by complexing with protein. ${ }^{27}$ The success of ulcer healing by the antimicrobials furazolidone ${ }^{28}$ and metronidazole, ${ }^{29}$ however, suggests that the bactericidal effect of bismuth may, indeed, be its mode of action. Thus evidence from treatment of duodenal ulcer is consistent with a dual pathogenesis of high acidity plus $C$ pyloridis infection.

Jenkins et al, in a detailed study to define duodenitis using quantitative histology, concluded that the mucosal response to injury "suggests a dual pattern of response-that is, an immune response reflected in changes in plasma cell populations and an acute inflammatory response closely related to the indicators of epithelial damage, gastric metaplasia, and villous atrophy". ${ }^{30}$ A combination of bacterial and chemical aggressive factors would account for this observation. Furthermore, they found an increase in all plasma cell types in duodenitis, but only the counts of IgG plasma cells correlated with polymorph infiltrate of the epithelium. We have previously shown that polymorph infiltration in active chronic gastritis is associated with the presence of Cpyloridis coated with IgG on the epithelial surface. $^{31}$

Although it is not yet established whether $C$ pyloridis are causally related to duodenal ulceration, we have found that the combination of significant gastric metaplasia in the duodenum and gastritis associated with $C$ pyloridis identifies those patients with active duodenitis, with a sensitivity of $88 \%$ and specificity of $98 \%$. The association is equally strong whether or not an ulcer crater was present, consistent with a common pathogenesis for duodenitis and duodenal ulceration.

We thank Dr BW Worsley for bacteriological assistance and Mrs $\mathrm{J}$ Fearnley for typing the manuscript.
References

1 Ippoliti A, Walsh J. Newer concepts in the pathogenesis of peptic ulcer disease. Surg Clin North Am 1976;56:1479-90.

2 Wormsley KG. The pathophysiology of duodenal ulceration. Gut 1974;15:59-81.

3 Hasan M, Sircus W, Ferguson A. Duodenal mucosal architecture in non-specific and ulcer-associated duodenitis. Gut 1981;22:637-41.

4 Cotton PB, Price AB, Tighe JR, Beals JSM. Preliminary evaluation of duodenitis by endoscopy and biopsy. Br Med J 1973;ii:430-3.

5 Joffe SN, Lee FD, Blumgart LH. Duodenitis. Clin Gastroenterol 1978;7:635-50.

6 James AH. Gastric epithelium in the duodenum. Gut 1964;5:285-94.

7 Patrick WJA, Denham D, Forrest APM. Mucosa change in the human duodenum: a light and electron microscopic study and correlation with disease and gastric acid secretion. Gut 1974;15:767-76.

8 Rhodes J. Experimental production of gastric epithelium in the duodenum. Gut 1964;5:454-8.

9 Earlam RJ, Amerigo J, Kakavoulis T, Pollock DJ. Histological appearances of oesophagus, antrum and duodenum and their correlation with symptoms in patients with a duodenal ulcer. Gut 1985;26:95-100.

10 Marshall BJ, McGechie DB, Rogers PA, Glancy RJ. Pyloric campylobacter infection and gastroduodenal disease. Med $J$ Aust 1985;142:439-44.

11 Rathbone BJ, Wyatt JI, Heatley RV. Campylobacter pyloridisa new factor in peptic ulcer disease? Gut 1986;27:635-41.

12 Steer HW. Surface morphology of the gastroduodenal mucosa in duodenal ulceration. Gut 1984;25:1203-10.

13 Grey SF, Wyatt JI, Rathbone BJ. Simplified techniques for identifying gastric Campylobacter pyloridis on tissue sections. $J$ Clin Pathol 1986;39:1279-80.

14 Whitehead R. Mucosal biopsy of the gastrointestinal tract. 3rd ed. Philadelphia: WB Saunders, 1984.

15 Rathbone BJ, Wyatt JI, Worsley BW, et al. Systemic and local antibody responses to gastric Campylobacter pyloridis in nonulcer dyspepsia. Gut 1986;27:642-7.

16 Marshall BJ, McGechie DB, Rogers PA, Glancy RJ. Pyloric campylobacter infection and gastroduodenal disease. Med $J$ Aust 1985;142:439-44.

17 Kreuning J, Bosman FJ, Kuiper G, Wal AM, Lindeman J. Gastric and duodenal mucosa in "healthy" individuals. J Clin Pathol 1978;31:69-77.

18 Shousha S, Spiller RC, Parkins RA. The endoscopically abnormal duodenum in patients with dyspepsia: biopsy findings in 60 cases. Histopathology 1983;7:23-34.

19 Steer HW. The gastroduodenal epithelium in peptic ulceration. $J$ Pathol 1985;146:355-62.

20 Steer HW. Ultrastructure of cell migration through the gastric epithelium and its relationship to bacteria. J Clin Pathol 1975;28:639-46.

21 O'Connor HJ, Axon ATR, Dixon MF. Campylobacter-like organisms unusual in type A (pernicious anaemia) gastritis. Lancet 1984; i:1091.

22 O'Connor HJ, Dixon MF, Wyatt JI, Axon ATR, Ward DC, Dewar EP, Johnston D. Effect of duodenal ulcer surgery and enterogastric reflux on Campylobacter pyloridis. Lancet 1986;ii:1178-81.

23 Johnson BJ, Reed PI, Ali MH. Relationship between the presence of duodenal campylobacter-like organisms and duodenal ulcer healing. Gut 1986;27:607-8A.

24 Martin DF, May SJ, Tweedle DEF, Hollanders D, Ravenscroft MM, Miller JP. Difference in relapse rates of duodenal ulcer after healing with cimetidine of tripotassium dicitrato bismuthate. Lancet 1981;i:7-10.

25 Hamilton I, O'Connor HJ, Wood NC, Bradbury I, Axon ATR. 
Healing and recurrence of duodenal ulcer after treatment with tri-potassium dicitrato bismuthate (TDB) tablets or cimetidine. Gut 1986;27:106-10.

26 Lee FI, Samloff IM, Hardman M. Comparison of tri-potassium dicitrato bismuthate tablets with ranitidine in healing and relapse of duodenal ulcers. Lancet 1985;i:1299-302.

27 Tygat GNJ, Paul ZM. De-Nol in the treatment of peptic ulcer. Scand J Gastroenterol 1982;17:(Suppl 80)1-60.

28 Zhi-Tian Z, Zheng-Ying W, Ya-Xian C, Yi-Nung L, Qiong-Fang L, San-Ren L, Zhao-Min X. Double-blind short-term trial of Furazolidone in peptic ulcer. Lancet 1985;i:1048-9.

29 Shirokova KI, Filomonov RM, Poliakova LV. Metronidazole in the treatment of peptic ulcer. Klin Med (Mosk) 1981;59:48-50.

30 Jenkins D, Goodall A, Gillet FR, Scott BB. Defining duodenitis: quantitative histological study of mucosal responses and their correlations. J Clin Pathol 1985;38:1119-26.

31 Wyatt JI, Rathbone BJ, Heatley RV. Local immune response to gastric Campylobacter in non-ulcer dyspepsia. J Clin Pathol 1986;39:863-70.

Requests for reprints to: Dr JI Wyatt, Department of $\stackrel{\overparen{D}}{\square}$

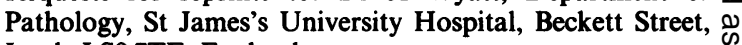
Leeds LS9 7TF, England. 